\title{
Sargassum seaweed extract as a novel green corrosion inhibitor for API-5L carbon steel
}

\author{
A. Nikitasari, (iD* Sundjono, G. Priyotomo and A. Royani \\ Research Center for Metallurgy and Material, Indonesian Institute of Sciences, Puspiptek \\ 470 Building, South Tangerang, 15313, Indonesia \\ *E-mail: arininikitasari89@gmail.com
}

\begin{abstract}
Sargassum extract was studied as a novel green corrosion inhibitor against the corrosion of API$5 \mathrm{~L}$ carbon steel in $0.1 \mathrm{M} \mathrm{HCl}$ solution. The inhibiting action of this extract was investigated using potentiodynamic polarization and electrochemical impedance spectroscopy (EIS). In addition, FTIR was employed to identify the main compound of Sargassum extract. The Sargassum extract was prepared by the maceration process. The maceration process takes $72 \mathrm{~h}$ to produce the filtrate. To obtain the Sargassum extract, the filtrate that resulted from the maceration process was evaporated. The inhibitor concentration was varied from $50 \mathrm{ppm}$, $100 \mathrm{ppm}, 200 \mathrm{ppm}, 400 \mathrm{ppm}$, to $500 \mathrm{ppm}$. Furthermore, the temperature and exposure time were also varied to determine their effect on the inhibitor efficiency. The temperature was varied as follows: room temperature, $40^{\circ} \mathrm{C}$, and $50^{\circ} \mathrm{C}$. The specimens were measured with two conditions, i.e., with and without pre-exposure for $30 \mathrm{~min}$. The inhibitor efficiency increased when inhibitor concentration, temperature, and exposure time increased according to the polarization test results. Interestingly, Sargassum extract (500 ppm) manifested inhibition efficiency up to $95 \%$ with 30 min exposure time. Moreover, the presence of aromatic rings $(\mathrm{C}=\mathrm{C})$, hydroxide $(\mathrm{O}-\mathrm{H})$, and organic compounds $(\mathrm{C}-\mathrm{H})$ was confirmed by FTIR. The results indicate that Sargassum seaweed extract is a good green corrosion inhibitor.
\end{abstract}

Received: October 12, 2021. Published: December 3, 2021 doi: $\underline{10.17675 / 2305-6894-2021-10-4-20}$

Keywords: Sargassum, API-5L, green corrosion inhibitor, potentiodynamic polarization, electrochemical impedance spectroscopy (EIS).

\section{Introduction}

API-5L carbon steel is the most adopted material in industries owing to its outstanding mechanical properties, low cost, and ease of supply [1]. However, API-5L carbon steel is prone to corrosion attack, especially in acid environments [2]. Corrosion of a metal is the degradation due to reactions with its environment $[3,4]$. Corrosion can be controlled by modifying the environment by addition of an inhibitor $[5,6]$.

A corrosion inhibitor is a chemical substance that reduces the corrosion rate [7]. Recently, the development of green inhibitors has attracted enormous attention because the use of inorganic inhibitors, particularly those containing phosphate, chromate, and other heavy metals, is now being gradually restricted by environmental regulations $[8,9]$. In 
addition, the use of synthetic organic inhibitors is now being limited due to their toxicity and high cost of manufacturing [10].

Green corrosion inhibitors are biodegradable and do not contain toxic or heavy metals [11]. In this study, Sargassum seaweed was used for the first time as a green corrosion inhibitor to decrease the corrosion rate of API-5L and take advantage of the massive amounts of this biomass, which has been found in recent years on the beach coasts of Indonesia [12]. The aim of this research was to evaluate Sargassum extract as a novel green corrosion inhibitor under potentiodynamic polarization, electrochemical impedance (EIS), and FTIR studies. Further, the effects of temperature, concentration, and exposure time on the inhibition efficiency were compared.

\section{Materials}

API-5L carbon steel with the chemical composition (wt.\%: $\mathrm{C}=0.05 ; \mathrm{Si}=0.13 ; \mathrm{Mn}=0.73$; $\mathrm{P}=0.02 ; \mathrm{S}=0.004 ; \mathrm{Fe}$ - remainder) was utilized to prepare the specimens used in this work. The microstructure of API-5L carbon steel is shown in Figure 1. API-5L carbon steel was cut into $1 \times 1 \mathrm{~cm}^{2}$ pieces and then connected with a cable wire. Prior to exposure in the $\mathrm{HCl}$ solution, the specimens were mounted with a resin and abraded using 120-1200 grit silicon carbide emery paper.

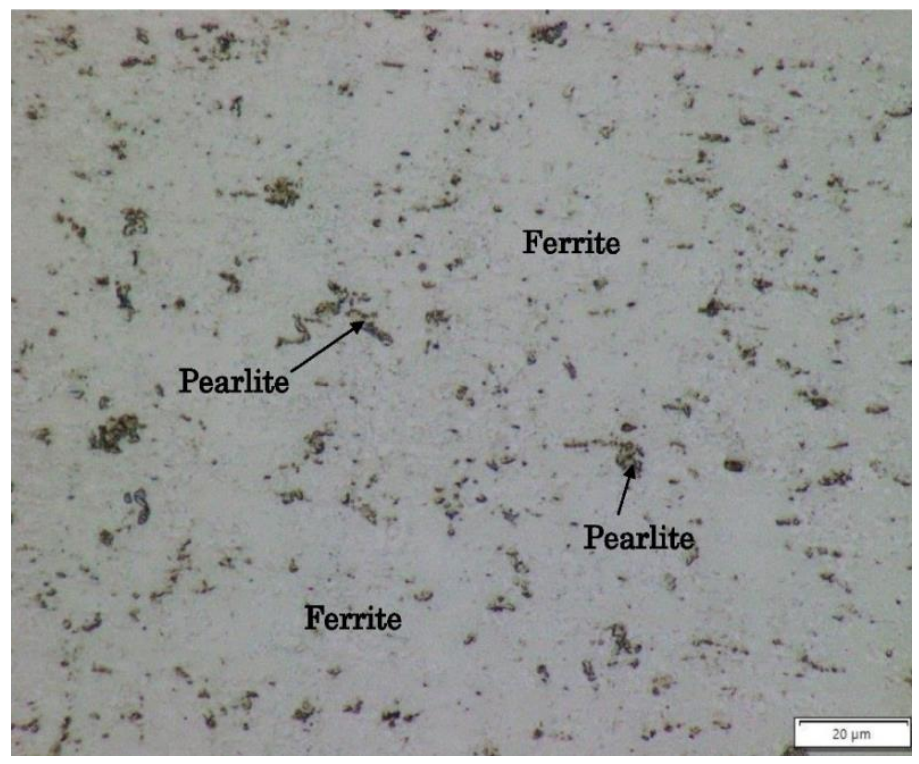

Figure 1. Microstructure of API-5L carbon steel.

\section{Sargassum extract and solution}

Sargassum extract was prepared via the maceration process. Prior to the maceration process, Sargassum was cleaned with tap water then dried for five days at room temperature. The dried Sargassum was chopped and collected in $70 \%$ of ethanol (maceration process) for $72 \mathrm{~h}$ at a Sargassum:ethanol ratio of 1:3. The maceration result was filtered and evaporated to 
obtain the extract. FTIR was employed to determine the compounds present in the Sargassum extract.

Hydrochloric acid $(\mathrm{HCl}) 0.1 \mathrm{M}$ was used as a solution in this experiment. Sargassum extract with concentrations from $0,50,100,200,400$, to $500 \mathrm{ppm}$ was added to $0.1 \mathrm{M} \mathrm{HCl}$. All specimens were immersed in the solution with and without exposure for $30 \mathrm{~min}$ before the test. The temperature of the solution was also varied (room temperature, $40^{\circ} \mathrm{C}$, and $50^{\circ} \mathrm{C}$ ) to study the effect of temperature on the corrosion rate.

\section{Potentiodynamic polarization and EIS test}

Potentiodynamic polarization and EIS tests were performed using a Gamry G-750 Corrosion Monitoring System in a typical three-electrode cell [13]. The cell components were a standard calomel electrode (SCE) as a reference electrode, a platinum counter electrode, and a previously mounted API-5L specimen as a working electrode. All electrodes were immersed in $0.1 \mathrm{M} \mathrm{HCl}$ with and without Sargassum extract during the test. Potentiodynamic polarization was performed in the potential range from $-250 \mathrm{mV}$ to $+250 \mathrm{mV}$ vs the established electrode potential at a scan rate of $1 \mathrm{mV} / \mathrm{s}$. The EIS tests were conducted in the frequency range from $100 \mathrm{kHz}$ to $10 \mathrm{mHz}$ with an amplitude of $10 \mathrm{mV}$.

\section{Result and Discussion}

\section{Potentiodynamic polarization measurements}

Figures 2-4 display the potentiodynamic polarization curves of API-5L in $0.1 \mathrm{M} \mathrm{HCl}$ with and without the inhibitor at different concentrations and temperatures. It is seen that the corrosion potential $\left(E_{\text {corr }}\right)$ tends to become a little nobler upon increasing the inhibitor concentration according to the polarization curves recorded without preliminary exposure (Figures 2(a)-4(a)). However, polarization curves recorded after $30 \mathrm{~min}$ exposure (Figures 2(b)-4(b)) show that the potential is nearly the same at various inhibitor concentrations due to the adsorption of the inhibitor. The similar values of the corrosion potential upon increasing inhibitor concentration indicated that Sargassum extract is a mixed-typed corrosion inhibitor [6].

Based on Figures 2-4, the corrosion current density $\left(I_{\text {corr }}\right)$ decreases on increasing the inhibitor concentration. This proves that Sargassum extract can improve the corrosion resistance of API-5L in an acid medium [14]. Furthermore, the smallest corrosion current density $\left(I_{\text {corr }}\right)$ is seen on the polarization curve with $500 \mathrm{ppm}$ of the inhibitor and $30 \mathrm{~min}$ exposure time. Therefore, at $500 \mathrm{ppm}$ and $30 \mathrm{~min}$ exposure time, the corrosion rate of API-5L is lower than in the other cases due to adsorption of Sargassum extract that inhibits the corrosive attack [15].

Table 1 lists the electrochemical parameters obtained from the polarization curves at room temperature. From Table 1, the corrosion current density is directly proportional to the corrosion rate. The corrosion current density and corrosion rate decrease with an increase in the inhibitor concentration. In addition, $30 \mathrm{~min}$ of exposure give Sargassum extract 
sufficient time to adsorb on the API-5L surface. Thus, the corrosion rate after $30 \mathrm{~min}$ of exposure is lower than that without the exposure.
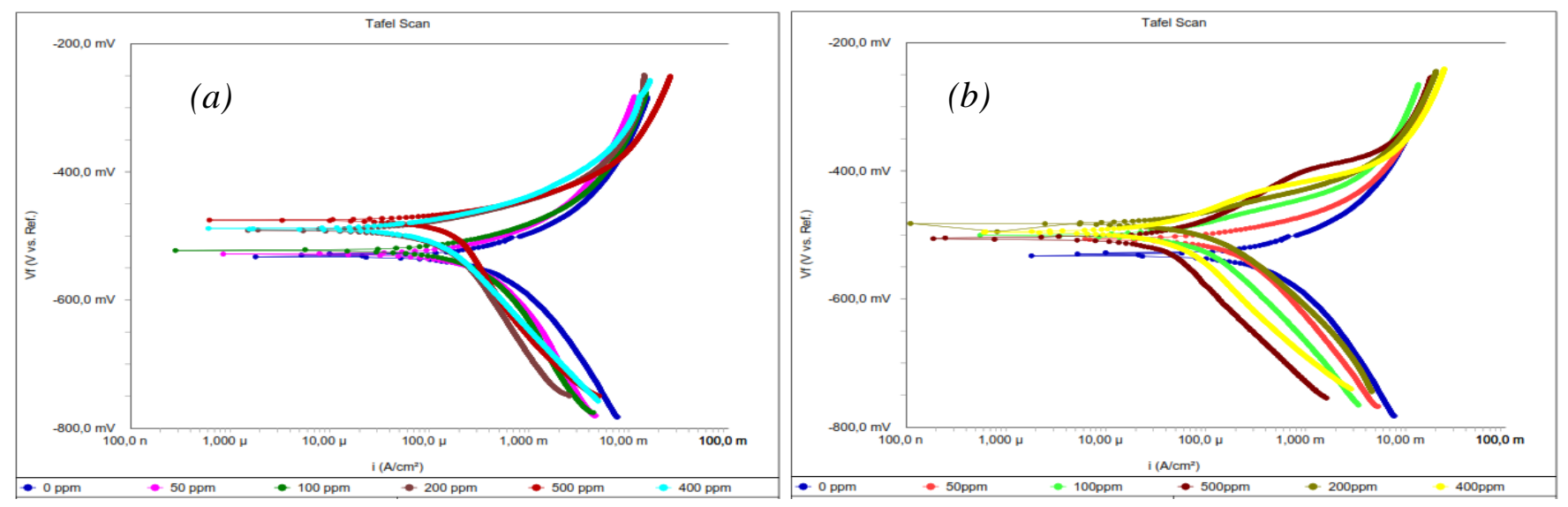

Figure 2. Potentiodynamic polarization curves of API-5L in $0.1 \mathrm{M} \mathrm{HCl}$ and various inhibitor concentrations at room temperature $(a)$ without exposure and $(b)$ with exposure for $30 \mathrm{~min}$.
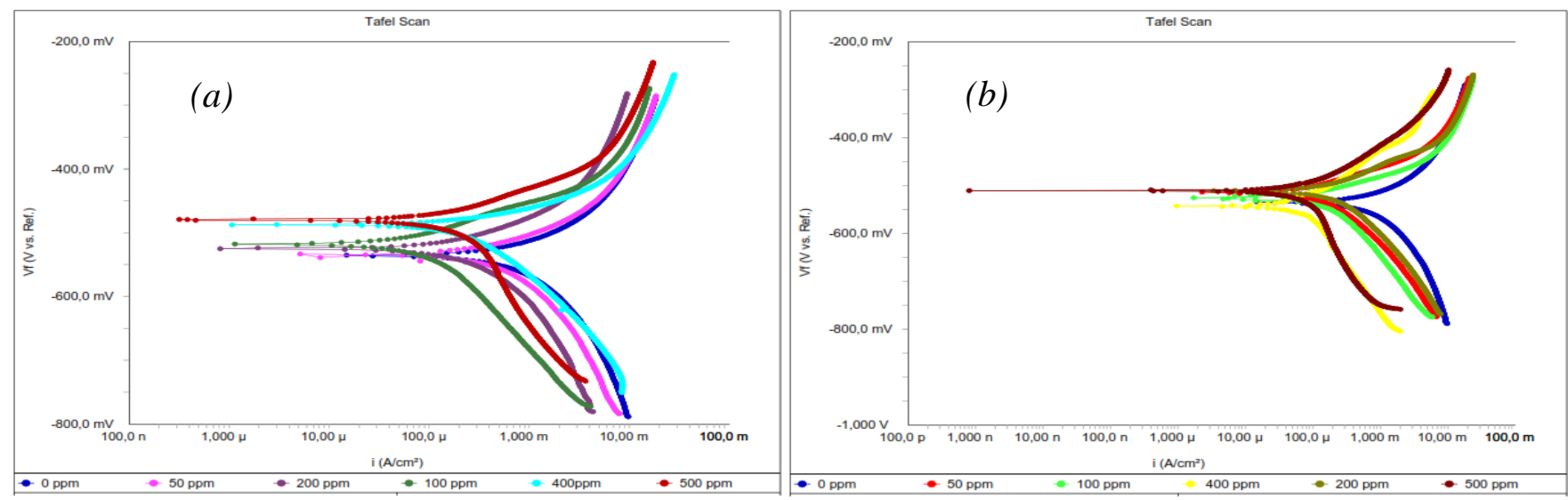

Figure 3. Potentiodynamic polarization curves of API-5L in $0.1 \mathrm{M} \mathrm{HCl}$ and various inhibitor concentrations at $40^{\circ} \mathrm{C}(a)$ without exposure and $(b)$ with exposure for $30 \mathrm{~min}$.
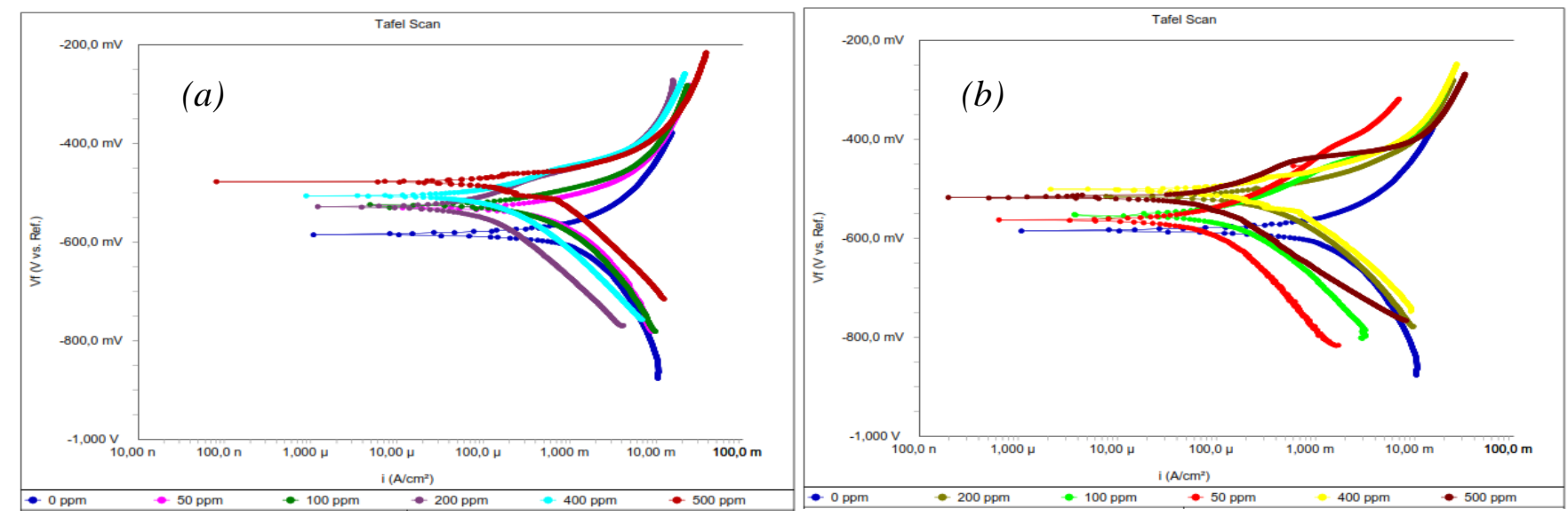

Figure 4. Potentiodynamic polarization curves of $\mathrm{API}-5 \mathrm{~L}$ in $0.1 \mathrm{M} \mathrm{HCl}$ and various inhibitor concentrations at $50^{\circ} \mathrm{C}(a)$ without exposure and $(b)$ with exposure for $30 \mathrm{~min}$. 
Table 1. Electrochemical parameters obtained from polarization curves at room temperature.

\begin{tabular}{ccccccc}
\hline \multirow{2}{*}{$\begin{array}{c}\text { Inhibitor } \\
\text { concentration } \\
(\mathbf{p p m})\end{array}$} & \multicolumn{3}{c}{ Without exposure } & \multicolumn{3}{c}{ Exposure for 30 min } \\
\cline { 2 - 7 } & $\begin{array}{c}\boldsymbol{E}_{\mathbf{c o r r}} \\
(\mathbf{m V})\end{array}$ & $\begin{array}{c}\boldsymbol{I}_{\mathbf{c o r r}} \\
\left(\mathbf{A} / \mathbf{m}^{\mathbf{2}}\right)\end{array}$ & $\begin{array}{c}\text { Corrosion } \\
\text { rate }(\mathbf{m p y})\end{array}$ & $\begin{array}{c}\boldsymbol{E}_{\mathbf{c o r r}} \\
(\mathbf{m V})\end{array}$ & $\begin{array}{c}\boldsymbol{I}_{\text {corr }} \\
\left(\mathbf{A} / \mathbf{m}^{\mathbf{2}}\right)\end{array}$ & $\begin{array}{c}\text { Corrosion } \\
\text { rate }(\mathbf{m p y})\end{array}$ \\
\hline 0 & -532 & $6.65 \cdot 10^{-4}$ & 304.70 & -532 & $6.65 \cdot 10^{-4}$ & 304.70 \\
50 & -528 & $4.91 \cdot 10^{-4}$ & 224.90 & -506 & $2.30 \cdot 10^{-4}$ & 105.50 \\
100 & -523 & $4.05 \cdot 10^{-4}$ & 185.70 & -500 & $1.01 \cdot 10^{-4}$ & 48.70 \\
200 & -491 & $1.52 \cdot 10^{-4}$ & 69.39 & -482 & $9.99 \cdot 10^{-4}$ & 45.78 \\
400 & -488 & $1.14 \cdot 10^{-4}$ & 52.20 & -496 & $4.09 \cdot 10^{-4}$ & 18.73 \\
500 & -475 & $8.76 \cdot 10^{-5}$ & 40.12 & -506 & $3.30 \cdot 10^{-4}$ & 15.12 \\
\hline
\end{tabular}

The inhibitor efficiency can be calculated from corrosion rate data using Equation 1 [16].

$$
\text { Inhibitor Efficiency }(\%)=\frac{C R-C R_{\text {in }}}{C R} \cdot 100 \%
$$

Where $C R$ is corrosion rate without the inhibitor and $C R_{\text {in }}$ is the corrosion rate with the inhibitor. Figure 5 illustrates the inhibitor efficiency for all the specimens. According to Figure 5, the inhibitor concentration, exposure time, and temperature boost the inhibitor efficiency. The efficiency of Sargassum extracts is up to 95\% at an inhibitor concentration of $500 \mathrm{ppm}$ and an exposure time of $30 \mathrm{~min}$. An increase in temperature accelerates the corrosion process as indicated by the increase in the corrosion rate. However, the inhibitor efficiency also increases with increasing temperature because temperature improves the surface chemisorption of Sargassum inhibitor [17].

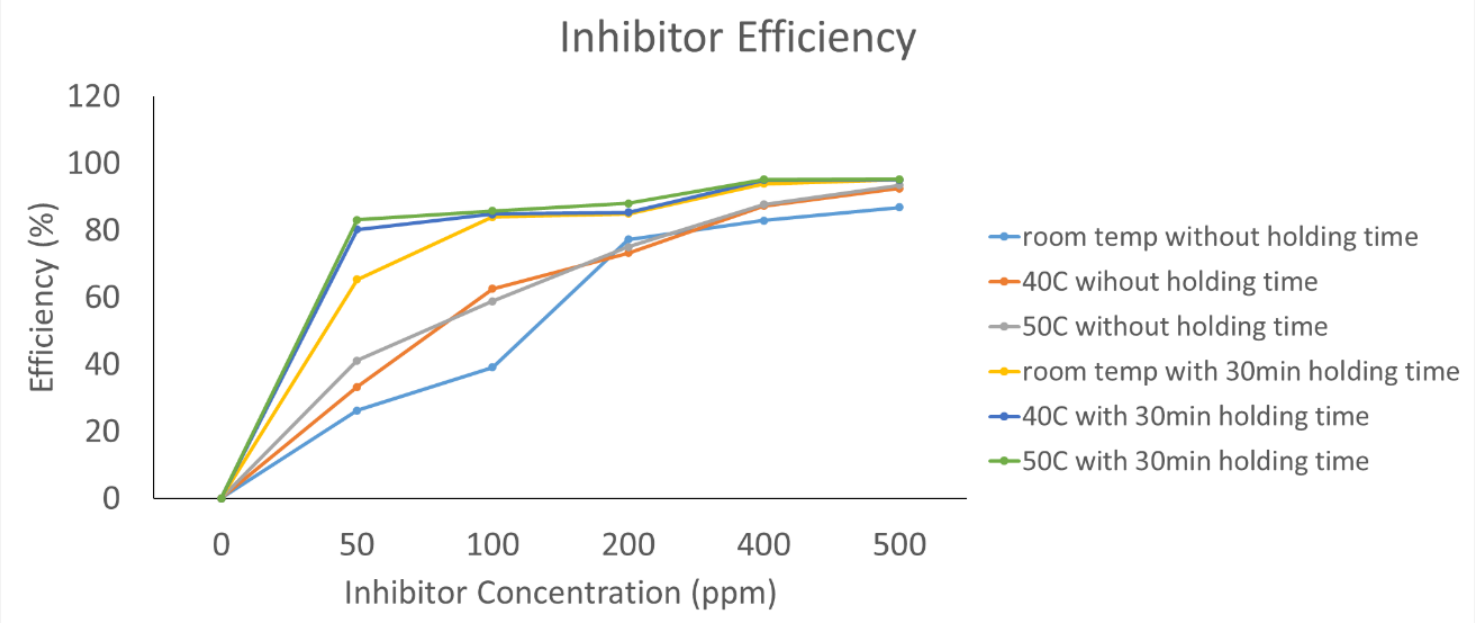

Figure 5. Inhibitor efficiency. 


\section{EIS test}

Besides potentiodynamic polarization, electrochemical impedance spectroscopy (EIS) was employed to investigate the inhibition performance of Sargassum extract. Figures 6-8 show the Nyquist plots of API-5L in $0.1 \mathrm{M} \mathrm{HCl}$ at various inhibitor concentrations and temperatures that resulted from the EIS test. It can be seen that the diameter of the semicircle increases with an increase in inhibitor concentration and the existence of exposure at each temperature. The diameter of the semicircle on the Nyquist plot represents the impedance of the system $[18,19]$ - the greater the impedance, the lower the corrosion rate. Therefore, the corrosion resistance of API-5L boosts with increasing inhibitor concentration and exposure time.

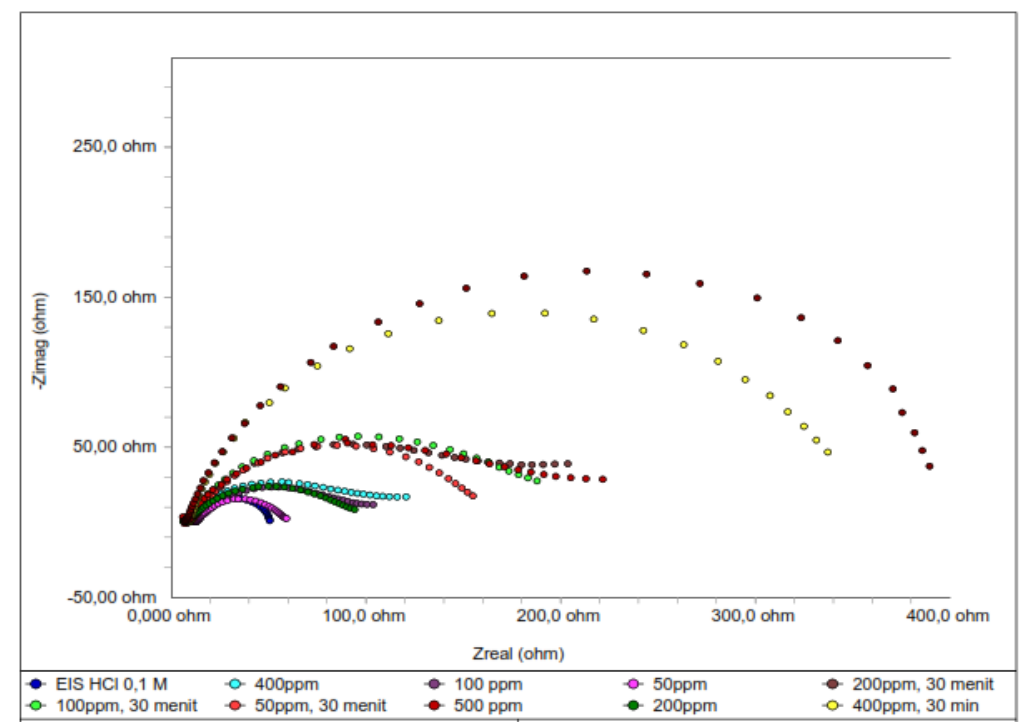

Figure 6. Nyquist plot of API-5L in $0.1 \mathrm{M} \mathrm{HCl}$ with various inhibitor concentrations at room temperature.

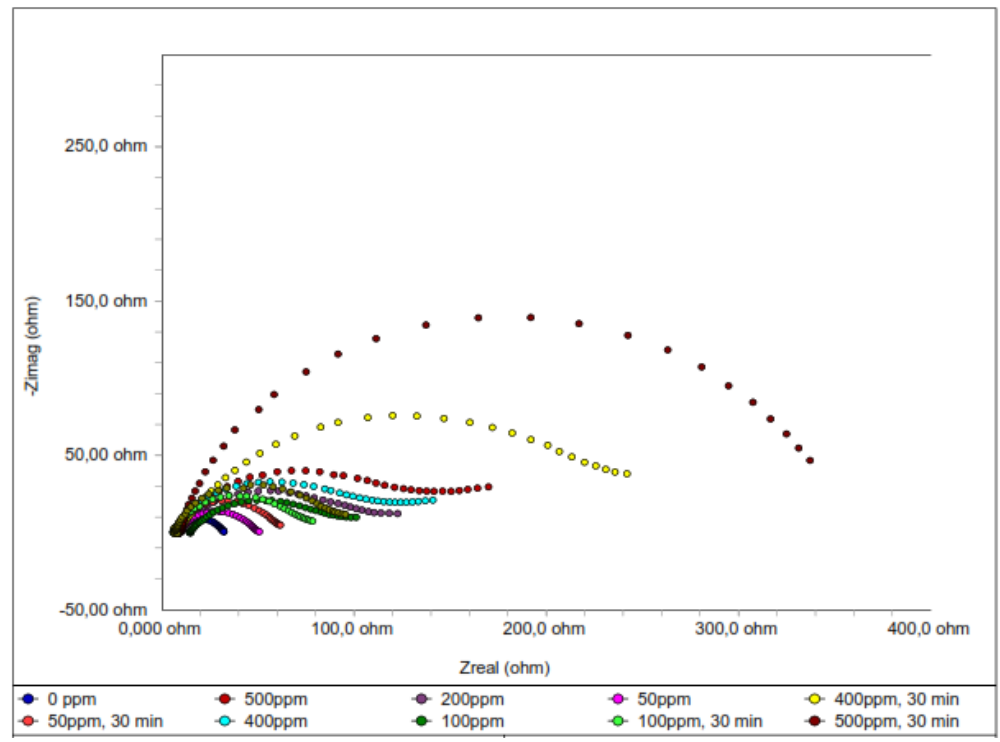

Figure 7. Nyquist plot of API-5L in $0.1 \mathrm{M} \mathrm{HCl}$ with various inhibitor concentrations at $40^{\circ} \mathrm{C}$. 


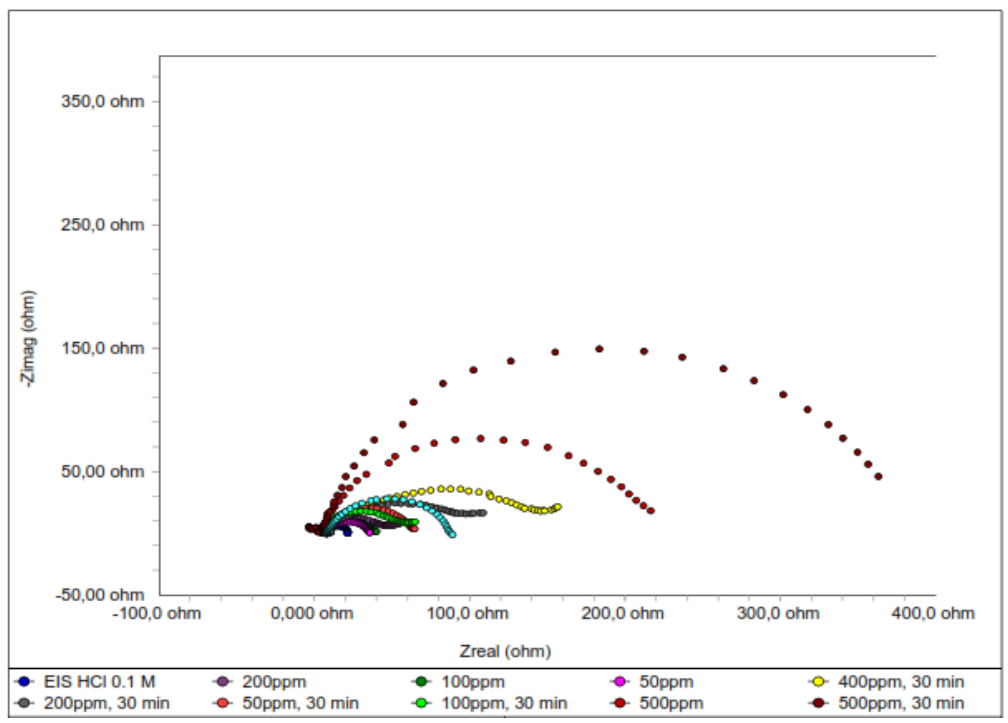

Figure 8. Nyquist plot of API-5L in $0.1 \mathrm{M} \mathrm{HCl}$ with various inhibitor concentrations at $50^{\circ} \mathrm{C}$.

To obtain more details on the electrochemical processes taking place during the test, an equivalent electrical circuit (Figure 9) was used to fit the Nyquist plot shown in Figure 6-8. The equivalent electrical circuit is composed of solution resistance $\left(R_{\mathrm{S}}\right)$, charge transfer resistance $\left(R_{\mathrm{ct}}\right)$, and a constant phase element (CPE). The CPE element includes $Y_{0}$ and " $\alpha$ " as the shift phase angle parameter [20]. The charge transfers resistances $\left(R_{\mathrm{ct}}\right)$ of all the specimens displayed in Figure 10. The value of $R_{\mathrm{ct}}$ reveals the total corrosion resistance performance [21]. According to Figure 10, the $R_{\mathrm{ct}}$ value increases with increasing inhibitor concentration and with pre-exposure.

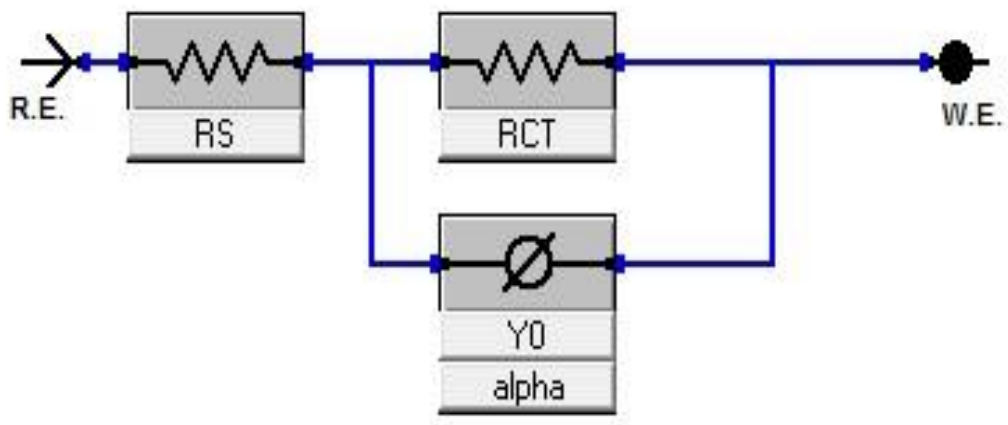

Figure 9. Equivalent electrical circuit. 


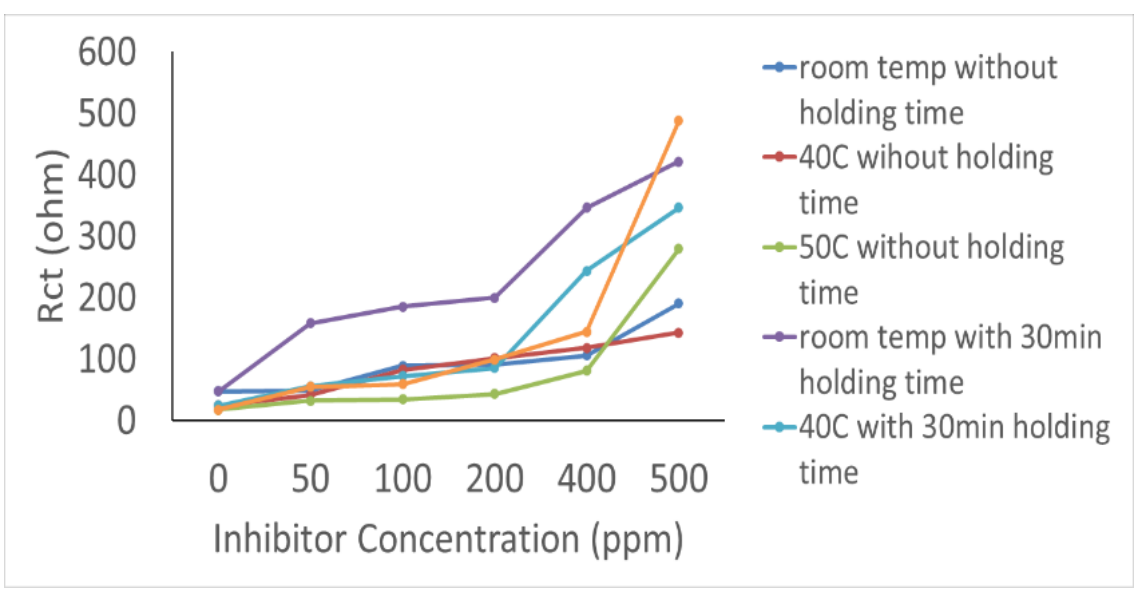

Figure 10. $R_{\mathrm{ct}}$ value.

\section{FTIR result}

Figure 11 shows Fourier Transform Infrared (FTIR) spectra of Sargassum seaweed extract. The intense peaks close to 2923, 2856, and $1457 \mathrm{~cm}^{-1}$ are associated with the stretching vibrations of the $\mathrm{C}-\mathrm{H}$ bond. The absorption peaks at 1561 and $721 \mathrm{~cm}^{-1}$ are attributed to the $\mathrm{C}=\mathrm{C}$ bond. The two bands at 3381 and $3339 \mathrm{~cm}^{-1}$ correspond to $\mathrm{O}-\mathrm{H}$. In addition, the peak at $1171 \mathrm{~cm}^{-1}$ is related to $\mathrm{C}-\mathrm{O}$. Finally, the presence of $\mathrm{C}=\mathrm{O}$ bonds is testified by the stretching vibrations occurring at a wavenumber of $1734 \mathrm{~cm}^{-1}$. Hence, Sargassum extract contains $\mathrm{O}, \mathrm{C}$, and $\mathrm{H}$ elements with asymmetric methyl and aromatic rings, which are attracted to the metal surface due to the existence of free electrons.

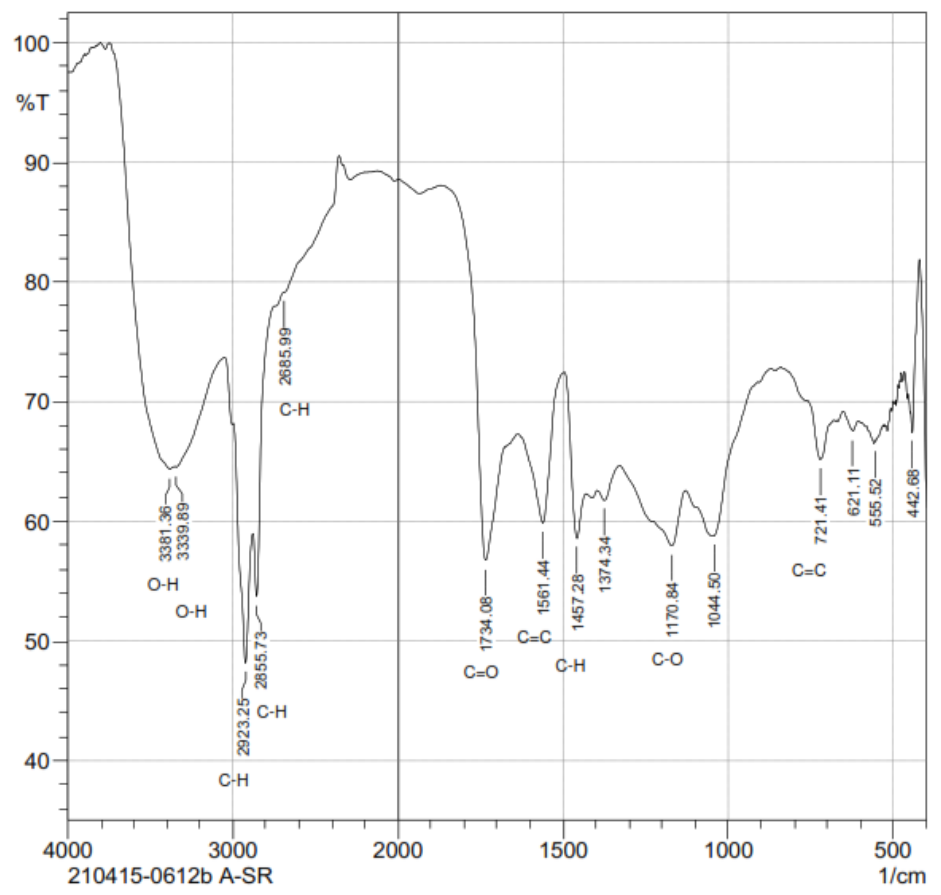

Figure 11. FTIR spectra of Sargassum seaweed extract. 


\section{Conclusion}

Sargassum seaweed extract inhibits the corrosion of API-5L carbon steel in the acid medium based on potentiodynamic polarization and electrochemical impedance spectroscopy (EIS) results. The concentration of Sargassum extract, temperature, and exposure time improve the efficiency of the inhibitor, with the highest value up to $95 \%$. According to EIS, the impedance or $R_{\mathrm{ct}}$ also increase with an increase in inhibitor concentration. Furthermore, Sargassum seaweed extract includes the organic compound, aromatic and asymmetric methyl functional group based on FTIR results. Therefore, Sargassum seaweed was successfully used for the first time as a green corrosion inhibitor for API-5L carbon steel.

\section{Acknowledgements}

This work was supported within the framework of National Research Programme managed by the Deputy of Earth Science of the Indonesian Institute of Sciences.

\section{References}

1. A. Belakhdar, H. Ferkous, S. Djellali, R. Sahroui, H. Lahbib, Y.B. Amor, A. Erto, M. Balsamo and Y. Benguerba, Colloids Surf., A, 2020, 606, 125458. doi: 10.1016/j.colsurfa.2020.125458

2. M. Chigondo and F. Chigondo, Recent Natural Corrosion Inhibitors for Mild Steel: An Overview, J. Chem., 2016, 2016, 6208937. doi: 10.1155/2016/6208937

3. M. Goyal H. Vashisht, A. Kumar, S. Kumar, I. Bahadur, F. Benhibaf and A. Zarrouk, Isopentyltriphenylphosphonium bromideionic liquid as a newly effective corrosion inhibitor on metal-electrolyte interface in acidic medium: Experimental, surface morphological (SEM-EDX \& AFM) and computational analysis, J. Mol. Liq., 2020, 316, 113838. doi: 10.1016/j.molliq.2020.113838

4. M. Goyal, S. Kumar, I. Bahadur, C. Verma, and E.E. Ebenso, Organic corrosion inhibitors for industrial cleaning of ferrous and non-ferrous metals in acidic solutions: A review, J. Mol. Liq., 2018, 256, 565-573. doi: 10.1016/j.molliq.2018.02.045

5. N.O. Eddy, S.A. Odoemelam, and I.N. Ama, Ethanol extract of Ocimum gratissimum as a green corrosion inhibitor for the corrosion of mild steel in $\mathrm{H}_{2} \mathrm{SO}_{4}$, Green Chem. Lett. Rev., 2010, 3, 165-172. doi: 10.1080/17518251003636428

6. Y. Liu, Z. Song, W. Wang, L. Jiang, Y. Zhang, M. Guo, F. Song and N. Xu, Effect of ginger extract as green inhibitor on chloride-induced corrosion of carbon steel in simulated concrete pore solutions, J. Cleaner Prod., 2019, 214, 298-307. doi: 10.1016/j.jclepro.2018.12.299

7. N. Al-Akhras and Y. Mashaqbeh, Potential use of eucalyptus leaves as green corrosion inhibitor of steel reinforcement, J. Build. Eng., 2021, 35, 101848. doi: $\underline{10.1016 / j . j o b e .2020 .101848}$ 
8. A. Singh, K.R. Ansari, D.S. Chauhan, M.A. Quraishi and S. Kaya, Anti-corrosion investigation of pyrimidine derivatives as green and sustainable corrosion inhibitor for N80 steel in highly corrosive environment: Experimental and AFM/XPS study, Sustainable Chem. Pharm., 2020, 16, 100257. doi: $10.1016 /$ j.scp.2020.100257

9. S.A. Asipita, M. Ismail, M.Z.A. Majid, Z.A. Majid, C. Abdullah and J. Mirza, Green Bambusa Arundinacea leaves extract as a sustainable corrosion inhibitor in steel reinforced concrete, J. Cleaner Prod., 2014, 67, 139-146. doi: 10.1016/j.jclepro.2013.12.033

10. H. Hassannejad and A. Nouri, Sunflower seed hull extract as a novel green corrosion inhibitor for mild steel in $\mathrm{HCl}$ solution, J. Mol. Liq., 2018, 254, 377-382. doi: 10.1016/j.molliq.2018.01.142

11. M.A. Bidi, M. Azadi and M. Rassouli, A new green inhibitor for lowering the corrosion rate of carbon steel in $1 \mathrm{M} \mathrm{HCl}$ solution: Hyalomma tick extract, Mater. Today Commun., 2020, 24, 100996. doi: 10.1016/j.mtcomm.2020.100996

12. M. Zhuang, J. Liu, X. Ding, J. He, S. Zhao, L. Wu, S. Gao, C. Zhao, D. Liu, J. Zhang and P. He, Sargassum blooms in the East China Sea and Yellow Sea: Formation and management, Mar. Pollut. Bull., 2021, 162, 111845. doi: 10.1016/j.marpolbul.2020.111845

13. A. Nikitasari, M.A. Prasetyo, R. Riastuti and E. Mabruri, Pitting corrosion resistance of CA6NM as geothermal turbine blade material in simulated artificial geothermal brine, IOP Conference Series: Materials Science and Engineering, 2019, 541, 012016. doi: 10.1088/1757-899X/541/1/012016

14. Y. Xu and M. Liu, Corrosion behaviors of polysiloxane-ferroferric oxide coating coated on carbon steel in $\mathrm{NaCl}$ solution and geothermal water, Geothermics, 2016, 70, 339350. doi: $10.1016 /$ j.geothermics.2017.08.001

15. X.H. Nie, X.G. Li, C.W.Du, and Y.F. Cheng, Temperature dependence of the electrochemical corrosion characteristics of carbon steel in a salty soil, J. Appl. Electrochem., 2009, 39, 277-282. doi: 10.1007/s10800-008-9669-1

16. A. Nikitasari, G. Priyotomo and A. Royani, Polyphosphate performance for inhibiting corrosion of heat exchanger materials, Int. J. Corros. Scale Inhib., 2020, 9, 745-756. doi: 10.17675/2305-6894-2020-9-2-22

17. A. Khavasfar, M.H. Moayed and A.H. Jafari, An investigation on the performance of an Imidazoline based commercial corrosion inhibitor on $\mathrm{CO}_{2}$ corrosion of mild steel, Int. J. Eng. Trans. A Basics, 2007, 20, 35-44.

18. M. Saremi and E. Mahallati, A study on chloride-induced depassivation of mild steel in simulated concrete pore solution, Cem. Concr. Res., 2002, 32, 1915-1921. doi: 10.1016/S0008-8846(02)00895-5

19. A. Nikitasari, E. Mabruri and R. Riastuti, Corrosion behavior of CA6NM in simulated geothermal brine highlighted by Electrochemical Impedance Spectroscopy (EIS), Eng. Appl. Sci. Res, 2021, 48, 359-367. doi: $\underline{\text { 10.14456/easr.2021.38 }}$ 
20. Z. Brytan, J. Niagaj and Ł. Reiman, Corrosion studies using potentiodynamic and EIS electrochemical techniques of welded lean duplex stainless steel UNS S82441, Appl. Surf. Sci., 2016, 388, 160-168. doi: 10.1016/j.apsusc.2016.01.260

21. Y. Liu, X. Yin, J. Zhang, S. Yu, Z. Han and L. Ren, A electro-deposition process for fabrication of biomimetic super-hydrophobic surface and its corrosion resistance on magnesium alloy, Electrochim. Acta, 2014, 125, 395-403. doi: 10.1016/j.electacta.2014.01.135 